Jurnal Matematika UNAND

Vol. VIII No. 1 Hal. 1-8

Edisi Mei 2019

ISSN : 2303-291X

(C)Jurusan Matematika FMIPA UNAND

\title{
ANALISIS KESTABILAN MODEL MANGSA PEMANGSA
}

\author{
Arezki Wahyu Pratama, Ahmad Iqbal Baqi \\ Program Studi S1 Matematika, \\ Fakultas Matematika dan Ilmu Pengetahuan Alam, Universitas Andalas, \\ Kampus UNAND Limau Manis Padang, Indonesia. \\ email : arezkiwahyupratama@yahoo.com
}

Diterima 9 Maret 2019 Direvisi 7 April 2019 Dipublikasikan 7 Mei 2019

\begin{abstract}
Abstrak. Interaksi antara satu spesies mangsa dengan satu spesies pemangsa dapat digambarkan dalam model Lotka-Volterra. Pertumbuhan populasi mangsa dipengaruhi oleh daya dukung lingkungan antara lain ruang, makanan dan organisme-organisme lain. Apabila daya dukung lingkungan terbatas maka jumlah populasi spesies mangsa yang dapat ditampung dalam lingkungan juga menjadi terbatas. Pertumbuhan populasi spesies mangsa yang dipengaruhi daya dukung lingkungan dapat digambarkan dalam model pertumbuhan logistik. Dari hasil penelitian dengan analisis titik tetap diperoleh tiga titik tetap dari model mangsa pemangsa dengan populasi spesies mangsa dipengaruhi daya dukung lingkungan.
\end{abstract}

Kata Kunci: Model Lotka-Volterra, Model Logistik, Kestabialn Titik Tetap.

\section{Pendahuluan}

Volterra (1926) pertamakali merumuskan model sederhana untuk pemangsaan dari satu spesies oleh satu spesies lain

$$
\begin{aligned}
& \frac{d x}{d t}=r x-p y x, \\
& \frac{d y}{d t}=-s y+q y x,
\end{aligned}
$$

Sistem (1.1) dikenal sebagai model Lotka-Volterra yang sebelumnya juga diturunkan oleh Alfred Lotka (1925) [?]. Pertumbuhan populasi spesies mangsa dipengaruhi oleh daya dukung lingkungan, yang digambarkan dalam model berikut :

$$
\frac{d N}{d t}=r N\left(1-\frac{N}{K}\right)
$$

Model (1.2) dikenal sebagai model pertumbuhan logistik yang diperkenalkan oleh Verhulst (1838).

Dengan memperhatikan model (1.1.2), model Lotka-Volterra (1.1.1) dapat dimodifikasi menjadi [?] : 


$$
\begin{aligned}
& \frac{d x}{d t}=r x\left(1-\frac{x}{K}\right)-p y x \\
& \frac{d y}{d t}=-s y+q y x
\end{aligned}
$$

dimana $x$ adalah jumlah populasi mangsa pada waktu $t, y$ adalah jumlah populasi pemangsa pada waktu $t, K$ adalah kapasitas daya dukung populasi mangsa, $r$ adalah pertumbuhan populasi mangsa tanpa adanya pemangsa, $p$ adalah konstanta kerapuhan (rentan) mangsa untuk dimangsa, $s$ adalah pertumbuhan populasi pemangsa tanpa adanya mangsa, dan $q$ adalah konstanta kemampuan memangsa dari spesies pemangsa, dimana $r, s, p, q$ dan $K$ merupakan konstanta positif.

Secara sederhana titik tetap $\mathbf{x}_{*}$ dari sistem (1.3) merupakan titik tetap stabil jika kurva solusi yang berawal dari $\mathbf{x}_{0}$, yang pada awalnya dekat dengan titik tetap tersebut, maka dengan bertambahnya waktu kurva solusi tersebut senantiasa dekat dengan titik tetap.

Suatu titik tetap $\mathbf{x}_{*}$ dari sistem (1.3) merupakan titik tetap stabil asimtotik jika titik tetap dari sistem tersebut stabil dan dengan bertambahnya waktu, kurva solusi dari sistem (1.3) akan semakin mendekat ke titik tetap, yaitu $\lim _{t \rightarrow \infty} \mathbf{x}(t)=\mathbf{x}_{*}$.

\section{Pembahasan}

Titik tetap dari sistem (1.3) memenuhi persamaan berikut :

$$
\begin{aligned}
r x\left(1-\frac{x}{K}\right)-p y x & =0, \\
-s y+q y x & =0 .
\end{aligned}
$$

Dari persamaan (2.1), diperoleh titik tetap dari sistem (1.3) berikut :

(1) $E_{0}=(0,0)$,

(2) $E_{1}=(K, 0)$

(3) $E_{2}=\left(\frac{s}{q}, \frac{r}{p}\left(1-\frac{s}{q K}\right)\right)$, dengan $0<\frac{s}{q K}<1$.

Matriks Jacobian dari model (1.3) adalah :

$$
\mathcal{J}\left(x^{*}, y^{*}\right)=\left[\begin{array}{cc}
r-\frac{2 r}{K} x-p y & -p x \\
q y & -s+q x
\end{array}\right] .
$$

Pada titik tetap $E_{0}$,

$$
\mathcal{J}_{E_{0}}=\left[\begin{array}{rr}
r & 0 \\
0 & -s
\end{array}\right] .
$$

Nilai eigen dari $\mathcal{J}_{E_{0}}$ adalah $\eta_{1}=-s$ dan $\eta_{2}=r$. Karena $r$ dan $s$ adalah konstanta positif, maka $\eta_{1}$ bernilai negatif dan $\eta_{2}$ bernilai positif sehingga titik tetap $E_{0}$ adalah titik saddle. Pada titik tetap $E_{1}$,

$$
\mathcal{J}_{E_{1}}=\left[\begin{array}{lr}
-r & -p K \\
0 & -s+q K
\end{array}\right] .
$$


Nilai eigen dari $\mathcal{J}_{E_{1}}$ adalah $\eta_{1}=-r$ dan $\eta_{2}=-s+q K$. Mengingat $r, s, q, K$ adalah konstanta positif maka $\eta_{1}<0$ dan

a. $\eta_{2}>0$ jika $s<q K$, sehingga titik tetap $E_{1}$ adalah titik saddle tidak stabil.

b. $\eta_{2}=0$ jika $s=q K$, sehingga titik tetap $E_{1}$ adalah titik tetap nonhiperbolik.

c. $\eta_{2}<0$ jika $s>q K$, sehingga titik tetap $E_{1}$ adalah titik node stabil.

Pada titik tetap $E_{2}=\left(\frac{s}{q}, \frac{r}{p}\left(1-\frac{s}{q K}\right)\right)$

$$
\begin{gathered}
\mathcal{J}_{E_{2}=}\left[\begin{array}{cr}
r-\frac{2 r s}{q K}-p\left(\frac{r}{p}\left(1-\frac{s}{q K}\right)\right) & -\frac{p s}{q} \\
q\left(\frac{r}{p}\left(1-\frac{s}{q K}\right)\right) & -s+q \frac{-}{q}
\end{array}\right] . \\
\mathcal{J}_{E_{2}}=\left[\begin{array}{lr}
-\frac{r s}{q K} & -\frac{p s}{q} \\
\frac{q r}{p}-\frac{r s}{p K} & 0
\end{array}\right] .
\end{gathered}
$$

Nilai eigen dari $\mathcal{J}_{E_{2}}$ adalah

$$
\eta_{1,2}=\frac{1}{2}\left[-\frac{r s}{q K} \pm \sqrt{\left.\left(\frac{r s}{q K}\right)^{2}\right)-4 r s\left(1-\frac{s}{q K}\right)}\right]
$$

Misalkan $\theta=-\frac{r s}{2 q K}$, maka $\theta$ akan selalu bernilai negatif. Karena $0<\frac{s}{q K}<1$ maka $4 r s\left(1-\frac{s}{q K}\right)$ akan selalu bernilai positif. Perhatikan yang berikut ini :

1 jika $\left(\frac{r s}{q K}\right)^{2}<4 r s\left(1-\frac{s}{q K}\right)$ maka nilai eigen dari $\mathcal{J}_{E_{2}}$ akan bernilai kompleks sehingga titik tetap $E_{2}$ adalah titik spiral stabil,

2 jika $\left(\frac{r s}{q K}\right)^{2}>4 r s\left(1-\frac{s}{q K}\right)$ maka nilai eigen dari $\mathcal{J}_{E_{2}}$ akan bernilai real dan berbeda sehingga titik tetap $E_{2}$ adalah titik node stabil,

3 jika $\left(\frac{r s}{q K}\right)^{2}=4 r s\left(1-\frac{s}{q K}\right)$ maka akan didapati nilai eigen dari $\mathcal{J}_{E_{2}}$ adalah nilai eigen kembar sehingga titik tetap $E_{2}$ adalah titik node improper stabil.

Sebagai ilustrasi, diberikan model berikut:

$$
\begin{aligned}
& \frac{d x}{d t}=3 x\left(1-\frac{x}{6}\right)-3 y x \\
& \frac{d y}{d t}=-y+2 y x
\end{aligned}
$$

dimana $x(0)=3, y(0)=2, r=3, p=3, s=1, q=2$, dan $\mathrm{K}=6$. Titik tetap dari model (3.0.8) adalah $E_{0}=(0,0), E_{1}=(6,0)$, dan $E_{2}=\left(\frac{1}{2}, \frac{11}{12}\right)$. Pada titik tetap $E_{0}$

$$
\mathcal{J}_{E_{0}}=\left[\begin{array}{rr}
3 & 0 \\
0 & -1
\end{array}\right]
$$


Nilai eigen dari $J_{E_{0}}$ adalah $\eta_{1}=3$ dan $\eta_{2}=-1$. Sehingga titik tetap $E_{0}$ adalah titik sadel tidak stabil.

Pada titik tetap $E_{1}$

$$
\mathcal{J}_{E_{1}}=\left[\begin{array}{lr}
-3 & -18 \\
0 & 11
\end{array}\right] .
$$

Nilai eigen dari $\mathcal{J}_{E_{1}}$ adalah $\eta_{1}=11$ dan $\eta_{2}=-3$. Sehingga titik $E_{1}$ adalah titik saddle tidak stabil.

Pada titik tetap $E_{2}$

$$
\mathcal{J}_{E_{2}}=\left[\begin{array}{lr}
-\frac{3}{12} & -\frac{3}{2} \\
\frac{33}{18} & 0
\end{array}\right] \text {. }
$$

Nilai eigen dari $\mathcal{J}_{E_{2}}$ adalah $\eta_{1,2}=-\frac{1}{8} \pm i \frac{\sqrt{5 \sqrt{7}}}{8}$ sehingga titik $E_{2}$ adalah titik spiral stabil.

\section{Kesimpulan}

Penelitian ini membahas model mangsa pemangsa

$$
\begin{aligned}
& \frac{d x}{d t}=r x\left(1-\frac{x}{K}\right)-p y x, \\
& \frac{d y}{d t}=-s+q y x .
\end{aligned}
$$

Dari model mangsa pemangsa tersebut diperoleh tiga titik tetap yaitu $(0,0),(K, 0)$ dan $\left(\frac{s}{q}, \frac{r}{p}\left(1-\frac{s}{q K}\right)\right)$, dimana $r, s, p, q$, dan $K$ masing-masingnya adalah pertumbuhan mangsa tanpa adanya pemangsa, pertumbuhan pemangsa tanpa adanya mangsa, konstanta kerapuhan (rentan) mangsa untuk dimangsa, konstanta kemampuan pemangsa untuk memangsa dan kapasitas daya dukung lingkungan untuk spesies mangsa. Adapun beberapa kesimpulan yang dapat diambil dari sistem diatas antara lain :

(i) Titik tetap $\left(\frac{s}{q}, \frac{r}{p}\left(1-\frac{s}{q K}\right)\right)$ berlaku jika $\frac{s}{q K}$ berada dalam selang $(0,1)$.

(ii) Titik tetap di $(0,0)$ adalah titik tetap yang bersifat saddle tidak stabil.

(iii) Dalam beberapa kondisi titik tetap yang stabil adalah titik tetap $(K, 0)$ dan titik tetap $\left(\frac{s}{q}, \frac{r}{p}\left(1-\frac{s}{q K}\right)\right)$. Kondisi tersebut antara lain :

a jika konstanta pertumbuhan populasi pemangsa tanpa adanya pemangsa lebih besar dari pada konstanta kemampuan pemangsa dikalikan dengan kapasitas daya dukung lingkungan.

b jika $\left(\frac{r s}{q K}\right)^{2}<4 r s\left(1-\frac{s}{q K}\right)$

c jika $\left(\frac{r s}{q K}\right)^{2}=4 r s\left(1-\frac{s}{q K}\right)$

d Jika $\left(\frac{r s}{q K}\right)^{2}>4 r s\left(1-\frac{s}{q K}\right)$ 


\section{Ucapan Terima kasih}

Penulis mengucapkan terima kasih kepada Bapak Prof. Dr. Muhafzan Bapak Dr. Mahdhivan Syafwan, Ibu Monika Rianti Helmi, M.Si dan Ibu Dr. Lyra Yulianti telah memberikan masukan dan saran sehingga hasil penelitian ini dapat diselesaikan dengan baik.

\section{Daftar Pustaka}

[1] Odum, Eugene P. 1971. Fundamental of Ecology. Thirth Edition. Rinehart and Winston, Inc. Athens.

[2] Dawed, Mohammed Yiha, Purnachandra Rao Koya, Temesgen Tibebu. 2015. Analysis of Prey-predator System with Prey Population Experiencing Critical Depensation Growth Function. American Journal of Applied Matematics. Vol. 3. No. 6. Hal. 327-334.

[3] Boyce, W.E. and Diprima, R.C. 1999. Ordinary Differential Equations and Boundary Value Problems. Fifth Edition. John Willey and Sons, Inc. New York.

[4] Zill, D. G. 2009. A First Course in Differential Equations with Modeling Application. Ninth Edition. Cengage Learning. Boston.

[5] Murray, J. D. 1989. Mathematical Biology. Thirth Edition. Springer. New York.

[6] Anton, H. 2005. Elementary Linear Algebra. Ninth Edition. Jhon Willey and Sons. New York.

[7] Gentle, J. E. 2007. Matrix Algebra. Springer. New York.

[8] Bellman, R. 1960. Introduction to Matrix Analysis. McGraw-Hill Company, Inc. New York.

[9] Lynch, S. 2007. Dynamical System with Application Using Mathematics. Birkhauser Boston. Cambridge. 